\title{
Inhibiting effects of neem seed oil on pathogenic and spoilage microorganisms of fresh-cut mango (Mangifera indica L.)
}

\author{
M. Kassé1,2, M. Cissé2, F. Charles'3, M.-N. Ducamp4, D. Montet and A. Guissé1,1,5,a \\ 1 Département de Biologie Végétale, Université Cheikh Anta Diop (UCAD), BP 5005, Dakar, Senegal \\ 2 Ecole Supérieure Polytechnique (ESP), UCAD, BP 5085, Dakar - Fann, Senegal \\ 3 UMR 95 Qualisud, Université d'Avignon, 84018 Avignon, France \\ ${ }^{4}$ CIRAD, UMR 95 Qualisud, TA B-95/16, Avenue Agropolis, 34398 Montpellier cedex 5, France \\ 5 Unité Mixte Internationale 3189 « Environnement, Santé, Société », CNRS, France
}

\section{Summary}

Introduction - This work proposed to use neem (Azadirachta indica) seed oil as an antimicrobial substance to improve the microbiological safety and quality of fresh-cut mango (Mangifera indica L.). Neem oil (NO) from seeds was tested in vitro and in vivo in volatile form or in incorporation into tryptic soy agar medium with nalidixic acid (TSAN) or in taro (Colocasia esculenta) starch based coating. Materials and methods - Antimicrobial effects of the volatile compounds of $\mathrm{NO}$ (at 30, 60, 80, 100 or $500 \mu \mathrm{L}$ ) and their incorporation $(1 \% \mathrm{v} / \mathrm{v})$ have been studied by two ways: in the medium of culture and in coating. Tests were done on the in vitro and in vivo growth of natural microbial flora, particularly the total aerobic mesophilic flora, total coliform, enterobacteria, yeasts, molds, and specifically on the inhibition of the growth of Escherichia coli K12 and Salmonella enterica subsp. enteritidis in fresh-cut mango. Results and discussion - The NO volatile were ineffective in vitro. However, the dose of $500 \mu \mathrm{L}$ greatly reduced the growth of common flora of fresh-cut mango fruit, allowing considering an in vivo study of their antimicrobial activities. In vivo, the NO volatiles reduced the growth of both organisms at 8 and 10 days of storage at $4{ }^{\circ} \mathrm{C}$. Neem oil incorporated in the culture medium slightly reduced the growth of $E$. coli $\mathrm{K} 12$ and had no significant effect on $S$. enterica subsp. enteritidis. Its incorporation into the starch coating was ineffective against the Salmonella strain and slightly reduced the growth of $E$. coli K12. Conclusion - This is the first study reporting the NO from seeds as potential antimicrobial substance against pathogenic and spoilage bacteria in fresh-cut fruit. Its use in food will require further studies to check the most effective dosage and perform the related toxicological tests.

Keywords

mango, Mangifera indica, Escherichia coli, Salmonella enterica, antimicrobial compound, food processing, fruit coating, shelf life

\section{Résumé}

Effets inhibiteurs de l'huile de graines de neem sur des microorganismes d'altération et pathogènes de la mangue 4 ème gamme.

\section{Significance of this study}

What is already known on this subject?

- Fresh-cut fruits have a very limited shelf life and could susceptibly be attacked by pathogenic microorganisms if poor hygienic practices are applied. Several essential oils are known for their antibacterial activity against Gram-negative bacteria.

What are the new findings?

- This work is the first study reporting neem seed oil as potential antimicrobial substance, in medium culture or in starch coating, against pathogenic bacteria like Escherichia coli K12 growing on fresh-cut mango.

What is the expected impact on horticulture?

- These findings are opening doors for improving fruit preservation and contributing to reduce postharvest losses in tropical countries where natural products can be locally produced and easily used as food preservative.

Introduction - Le présent travail propose l'utilisation de l'huile de graines de neem (Azadirachta indica) en tant que substance antimicrobienne employée in vitro et in vivo en volatil ou en incorporation dans le milieu de culture gélosé trypticase soja (TSAN) ou dans un enrobage à base d'amidon de taro (Colocasia esculenta) pour l'amélioration de la qualité microbiologique des mangues $4^{\mathrm{ème}}$ gamme (Mangifera indica L.). Matériel et méthodes - L'effet antimicrobien des composés volatils des huiles de graines de neem (doses de 0,30 , $60,80,100$ et $500 \mu \mathrm{L}$ ), ainsi que leur incorporation $(1 \% \mathrm{v} / \mathrm{v})$ dans le milieu de culture et dans l'enrobage, ont été étudiés sur la croissance in vitro et in vivo de la flore microbienne des mangues 4 ème gamme, particulièrement la flore mésophile aérobie totale, les coliformes totaux, les entérobactéries, les levures, les moisissures et spécifiquement sur l'inhibition de la croissance de Escherichia coli K12 et de Salmonella enterica subsp. enteritidis. Résultats et discussion - Les résultats montrent que les volatils de l'huile de neem sont inefficaces in vitro. Par contre, la dose de $500 \mu \mathrm{L}$ réduit fortement la croissance de la flore banale des mangues 4ème gamme, permettant d'envisager une étude antimicrobienne in vivo et en incorporation

a Corresponding author: alguisse@orange.sn. 
sur ce produit. In vivo, les volatils réduisent la croissance des deux germes aux 8 ème et 10 ème jours de conservation à $4{ }^{\circ} \mathrm{C}$. L'huile de graines de neem incorporée au milieu de culture a réduit légèrement la croissance de $E$. coli K12. Son incorporation dans l'enrobage d'amidon s'est montrée inefficace contre $S$. enterica subsp. enteritidis et a légèrement réduit la croissance de $\boldsymbol{E}$ coli K12. Conclusion - Il s'agit de la première étude signalant l'huile de graines de neem comme substance antimicrobienne potentiellement efficace contre les bactéries pathogènes et d'altération des fruits 4 ème gamme. Son utilisation sur les aliments nécessite de plus amples études pour vérifier le dosage le plus efficace et tester les effets toxicologiques.

\section{Mots-clés}

mangue, Mangifera indica, Escherichia coli, Salmonella enterica, composé antimicrobien, transformation alimentaire, enrobage de fruits, durée de vie

\section{Introduction}

Preservation of fresh fruit is limited because of their increasing respiratory activity after harvest. Fresh-cut fruits have a very limited shelf life due to peeling, trimming, cutting and handling during processing. Therefore, these kinds of products could be susceptible to attack by pathogenic microorganisms if poor hygienic practices are applied (Sandhya, 2010). This vulnerability can be reduced by several post-harvest techniques of preservation.

Despite modern hygiene techniques used to improve food production, food safety has become an important challenge for public health (World Health Organization [WHO], 2002). The search for new methods to reduce pathogens in food is always a particular challenge. For fresh-cut products, the use of natural compounds with multiple biological properties including those having antimicrobial properties has rapidly developed over the past decade.

Thus, some in vitro studies have demonstrated the antibacterial activity of essential oils against Listeria monocytogenes, Salmonella typhimurium, Escherichia coli 0157: H7, Shigella dysenteriae, Bacillus cereus and Staphylococcus aureus at a level between 0.2 and $10 \mu \mathrm{L} \mathrm{mL}^{-1}$ in solution used for washing fruit and vegetables (Burt, 2004). Thus, the neem tree (Azadirachta indica A. Juss.), its plant parts and its extraction compounds were characterized for their multiple biological and pharmacological properties (Sunday and Joy, 2009) and their multipurpose activities (Pu et al., 2010) such as ovicidal, antifungal, acaricidal, immuno-stimulant, medicinal, pharmaceutical, and antibacterial; giving it the name of "tree of thousand virtues". Neem oil extracted from the seeds has been recognized effective, in vitro, against external pathogens (especially fungi) (Sagoua, 2009) and internal pathogens of fruits (e.g., Escherichia coli and Salmonella infantis) (Alzoreky and Nakahara, 2003).

The antibacterial activity of neem oil was also tested in vitro, in Petri dish, in agar and in tube of dilution broth, against strains of Pseudomonas aeruginosa, Staphylococcus aureus, Escherichia coli, Proteus spp., and Klebsiella aerugenes (Pai et al., 2004). The use of these methods (Alzoreky and Nakahara, 2003; Burt, 2004) also demonstrated the antibacterial effect of neem extracts against Bacillus cereus, Escherichia coli, and Salmonella infantis. It was the same effect against bacteria such as Streptococcus mutans and Lactobacillus spp. (Vanka et al., 2001), Klebsiella pneumoniae (Sairam et al., 2000), Streptococcus faecalis (Almas, 1999), Helicobacter pylori (Fabry et al., 1996) and many other types of pathogenic bacteria in India and East Africa (Fabry et al., 1998). Other studies have also shown that different neem extracts had antibacterial activity against fish pathogens such as Aeromonas hydrophila, Pseudomonas fluorescens, E. coli and Myxobacteria (Burt, 2004; Das et al., 1999), as well as other microorganisms such as Vibrio cholera, Mycobacterium tuberculosis and Mycobacterium pyogenes (Biswas et al., 2002), which are of major public health importance.

This study proposes using neem oil and in particular its volatile compounds, as an antimicrobial substance to improve the microbiological quality of fresh-cut mango and specifically its effect on in vitro and in vivo growth of two of its pathogens such as Escherichia coli $\mathrm{K} 12$ and Salmonella enterica subsp. enteritidis.

\section{Materials and methods}

\section{Mango}

Various cultivars of mango (Mangifera indica L.) were used in this study based on the availability of this raw material on the market. 'Keitt' (Size B, Category I, of Dominican Republic origin and Size A, Category I, Israeli origin) and 'Kent' (Senegalese origin) were purchased in a supermarket in Montpellier (France), or were imported from Senegal to France.

Whole mango fruits $(\mathrm{pH}=4.5$ and total soluble solids = $13^{\circ} \mathrm{Brix}$ ) were washed during $1 \mathrm{~min}$ in a chlorinated water bath (100 ppm at pH 4.5 adjusted with citric acid). Then, fruits were peeled, trimmed and cut into cubes $(2 \times 2 \mathrm{~cm})$ with a sharp knife in stainless steel to avoid traumatizing the tissue. For cubes, the two "mango cheeks" were cut longitudinally and transversely.

\section{Neem plant material and oil extraction}

Neem oil (NO) used in this study was obtained from the seeds of neem trees (Azadirachta indica) collected in Thiès by the Senegalese Institute of Agricultural Research (ISRA). The oil extraction was carried out by "cold" (ambient temperature of the laboratory) mechanical pressure (Sagoua, 2009) from the seeds of neem previously washed and dried at $55^{\circ} \mathrm{C}$ for $48 \mathrm{~h}$. The filtration method was performed using a micrometer sterile filter (Milex $0.45 \mu \mathrm{m}$, blue) in order to eliminate impurities as well as microbial contaminants. The filtered oil was then stored at $4{ }^{\circ} \mathrm{C}$ before use.

\section{Formulation of taro starch based coating}

The taro starch (Colocasia esculenta) and the method for formulating the coating were provided by the Instituto de Ciencia y Tecnología de Alimentos (ICTA), Facultad de Ciencias at Universidad Central de Venezuela. The coating solution was prepared in distilled water with $5 \%(\mathrm{w} / \mathrm{v})$ starch powder of Colocasia esculenta and 2.5\% (w/v) Glycerol (Tapia et al., 2011; Pérez et al., 2011). Starch and water were first homogenized with an Ultra Turrax T25 (IKA ${ }^{\circledR}$ Werke). Thereafter, glycerol was added to the homogeneous mixture prior to gelatinization of the starch solution in a water bath at $95{ }^{\circ} \mathrm{C}$ for $30 \mathrm{~min}$ under constant magnetic stirring. After gelatinization, each gel suspension was degassed for $15 \mathrm{~min}$ using a mechanical vacuum pump. 


\section{Bacterial strains studied}

The studied strains of bacteria were Escherichia coli $\mathrm{K} 12$ and Salmonella enterica subsp. enteritidis. The E. coli K12 strain was provided in slanted agar tubes by the Microbiology Laboratory of the University of Montpellier II where S. enterica subsp. enteritidis was bought from Institute Pasteur in Paris. The strains were then stored at $4{ }^{\circ} \mathrm{C}$ until used. Inocula were prepared from these strains according to Strawn and Danyluk (2010) and used for the contamination of cubes. A volume of 1,000 mL of inoculum at $10^{3} \mathrm{CFU} \mathrm{mL}^{-1}$, previously selected after several tests, was prepared in peptone water $0.1 \%$ for each bacteria.

\section{Effect of neem oil volatile on the in vitro growth of $E$. coli $\mathrm{K} 12$ and $S$, enterica subsp. enteritidis}

Cultures of both bacteria were performed on trypticase soy agar (TSA) containing nalidixic acid $0.25 \%$ (NA) or TSAN. Nalidixic acid is a selective antibiotic for enumeration of $E$. coli and Salmonella, only in TSA medium.

Five aliquots of neem oil (NO): 30, 60, 80, 100 and $500 \mu \mathrm{L}$ were deposited on a microscope strip fixed with glycerol to the bottom of the Petri dish cover (Sagoua, 2009) to study the treatment of neem oil volatile compounds. The control batch was inoculated on Petri dish without NO $(0 \mu \mathrm{L})$ volatile compound treatment. Three (3) replicates per treatment were carried out. For inoculation, a volume of $50 \mu \mathrm{L}$ of each strain inoculum was spread on TSAN medium. All inoculated Petri dishes were then incubated at $37{ }^{\circ} \mathrm{C}$ for $24 \mathrm{~h}$ before reading the results. The results were processed by MS Excel and the bacterial charge ( $\mathrm{N}$ in $\mathrm{CFU} \mathrm{mL} \mathrm{mL}^{-1}$ ) were calculated applying the formula below:

$$
N=\frac{\sum \text { Colonies }}{V m L \times(n 1+0.1 \times n 2) \times D}
$$

where CColonies is the sum of the numbers of bacterial colonies in considered Petri dish; $N$ is the number of CFU g-1 (or $\mathrm{mL}^{-1}$ ) per initial product; $V m L$ is the volume in $\mathrm{mL}$ sowed; $n 1$ and $n 2$ are the number of interpretable Petri dishes of the $1^{\text {st }}$ and $2^{\text {nd }}$ inoculated dilutions; and $D$ is the dilution factor of the $1^{\text {st }}$ dilution considered. The results were then expressed as $\log 10(\mathrm{~N})$.

\section{Effect of neem oil volatile on the growth of common flora of fresh-cut mango}

Assessment of the microbiological quality of fresh-cut mango was done by counting the natural microbial flora, in particular coliform, total aerobic count, enteric bacteria yeasts and molds on $3 \mathrm{M}$-Petrifilm ${ }^{\mathrm{TM}}$ specific test for each of the microorganism groups. Thus for sampling, the mango cubes were filled in tray, and separated in two batches. A batch was treated with $500 \mu \mathrm{L}$ of the neem oil volatiles deposited in a mini cap of $3 \mathrm{~cm}$ in diameter attached in the corner of each sample tray. The samples were then packed with a stretchable plastic film and stored at $4{ }^{\circ} \mathrm{C}$ for one week (7 days). The microbiological checks were done at the end of 7 days on specific $3 \mathrm{M}$-Petrifilm ${ }^{\mathrm{TM}}$ tests.

After the preparation of stock suspensions $\left(D_{0}=10^{-1}\right)$ and its decimal dilutions in phosphate buffer $(\mathrm{pH}=7), 1 \mathrm{~mL}$ of $\mathrm{D}_{1}$ $\left(10^{-2}\right), \mathrm{D}_{2}\left(10^{-3}\right)$ and $\mathrm{D}_{3}\left(10^{-4}\right)$ dilutions were deposit in the middle of the Petrifilm ${ }^{\mathrm{TM}}$ and spread with a diffuser (provided with the Petrifilm $^{\mathrm{TM}}$ ) by exerting a light finger press. After inoculation, Petrifilm ${ }^{\mathrm{TM}}$ were incubated at $30^{\circ} \mathrm{C}$ for $48 \mathrm{~h}$ for enumeration of total aerobic count (AC); at $37^{\circ} \mathrm{C}$ for $24 \mathrm{~h}$ for coliform count (CC) and enterobacteria (EB) and at $20-25^{\circ} \mathrm{C}$ for 3 to 5 days for the enumeration of yeasts $(\mathrm{Y})$ and molds $(\mathrm{M})$.

Counting on Petrifilm ${ }^{\mathrm{TM}}$ was done according to the $3 \mathrm{M}$-method. The 3M-tests were provided with a circular growth area of $20 \mathrm{~cm}^{2}$ divided into 20 squares of $1 \mathrm{~cm}^{2}$ that allows easy reading of results. In addition, because of their high cost and the benefit they provide for accurate growing, only one Petrifilm ${ }^{\mathrm{TM}}$ per dilution was sowed. In the 3M-tests containing more than 100 to 150 colonies (depending of the germs), the results were estimated by counting the number of colonies in at least two representative squares. The average number per square was then determined and multiplied by 20 to give the estimated number of strains per Petrifilm ${ }^{\mathrm{TM}}$ test.

Results of this study were used as reference for assessing the effect of neem oil volatile compounds on the in vivo growth of tested bacteria.

\section{Effect of neem oil volatile on the in vivo growth of $E$. coli K12 and $S$. enterica subsp. enteritidis}

This experience, also known as "Challenge test" consisted in contaminating bleached mango cubes (in chlorinated water bath at $10 \mathrm{ppm}$ during $1 \mathrm{~min}$ ) with inoculum of each strain separately. Before inoculum dipping treatment, mangoes cubes were washed with sterile water to eliminate the residual chlorine. Indeed, mango cubes were divided in two batches of 150 cubes each. One batch was dipped for $1 \mathrm{~min}$ in the inoculum of E. coli $\mathrm{K} 12$ and the other in the inoculum of $S$. enterica subsp. enteritidis. After draining, five (5) cubes were sampled in each tray (30 units of samples trays for each batch or each bacteria). Then 15 samples trays of each batch were treated with $500 \mu \mathrm{L}$ NO volatiles under the same conditions as the previous study in paragraph 2.6; and the others were used as controls (Ctrl) of both. The samples were stored at $4{ }^{\circ} \mathrm{C}$ for 10 days before being subjected to microbiological tests.

Every 2 days (1, 3, 6, 8 and 10 days of storage), 3 samples trays were taken from each batch for microbiological tests. After sample grinding in a stomacher and preparation of the stock suspension $\left(D_{0}=10^{-1}\right)$ and its $D_{1}\left(10^{-2}\right)$ and $D_{2}\left(10^{-3}\right)$ dilutions, $50 \mu \mathrm{L}$ of these two dilutions were plated on TSAN Petri dish. Plates were then incubated at $37{ }^{\circ} \mathrm{C}$ for $48 \mathrm{~h}$.

\section{Effect of neem oil on the in vitro growth of both studied germs}

This experiment was performed under the same conditions as the experiment in paragraph 2.7, the difference thereof, was the incorporation of $1 \%(\mathrm{v} / \mathrm{v})$ of filtered raw neem oil into the sterilized TSAN medium (TSAN $+1 \%$ NO samples). Controls (TSAN samples) consisted of the growing medium without neem oil.

\section{Effect of neem oil in Colocasia esculenta starch based coating on the in vivo growth of $E$. coli $\mathrm{K} 12$}

The filtered neem oil (NO) was incorporated in the coating after degassing and cooling at a concentration of $1 \%(\mathrm{v} / \mathrm{v}) ; 10 \mathrm{~mL} \mathrm{NO}$ was added to $990 \mathrm{~mL}$ of the coating solution. The coating solution was stored at $4{ }^{\circ} \mathrm{C}$ before use for the treatment of cubes. The treatment of mango fruit samples in the inoculum of strains, in the coating and in the coating containing $1 \%$ NO was carried out by soaking cubes in the solutions during $1 \mathrm{~min}$. Thus three batches of samples were obtained: a first batch treated with the inoculum solution representing the controls (Ctrl), a second group treated with the inoculum and then coated were the coated 
samples (C) and a third group treated with the inoculum and then the coating containing 1\% NO (v/v) (CNO samples). These samples were stored at $4^{\circ} \mathrm{C}$ for 10 days before being subjected to microbiological assessment.

Every 5 days $(1,6$, and 10 days of storage), 3 samples were taken from each batch for microbiological assessment. Thus, after preparing the stock suspension and its decimal dilutions, $50 \mu \mathrm{L}$ of $\mathrm{D}_{2}\left(10^{-3}\right)$ and $\mathrm{D}_{3}\left(10^{-4}\right)$ dilutions were spread on TSAN plates (Petri dish) within three (3) replicates of plates per dilution. Inoculated plates were incubated at $37^{\circ} \mathrm{C}$ for $48 \mathrm{~h}$ before counting.

\section{Results and discussion}

\section{Effect of neem oil on the in vitro growth of $E$. coli $\mathrm{K} 12$ and S. enterica subsp. enteritidis}

Neem oil (NO) volatile compounds did not reduce the in vitro growth of both bacteria (Figure 1) compared to control treatment ( $0 \mu \mathrm{L}$ NO). Thus, the growth of E. coli K12 was the same for all treatments. But, there was a significant increase of the in vitro growth of $S$. enterica subsp. enteritidis with the treatments of 60,80 and $100 \mu \mathrm{L} \mathrm{NO}$.

Few works are available on the in vitro antibacterial activity of neem oil volatile compounds on fresh-cut fruit pathogenic. Most of the work done on the in vitro antibacterial effect of essential oils have been reported by Burt (2004) for most on soil samples (Sunday and Joy, 2009), water (Matthews et al., 2009) and in some other cases neem oil suspensions were incorporated and dispersed with solvent, or inoculated in matrices, either for washing-disinfecting fruit and vegetables or incorporated in dispersed broth or agar medium or in direct contact with the studied strains (Pu et al., 2010; Alzoreky and Nakahara, 2003; Pai et al., 2004; Pintore et al., 2002; Prudent et al., 1995).

Recent research papers (Mamman et al., 2013; Ravva and Korn, 2015; Raut et al., 2014; Uwimbabazi et al., 2015), using the same methods, showed various results on NO antibacterial activity against in vitro growth of E. coli and Salmonella strains. Raut et al. (2014) demonstrated that leaf and bark extract of Azadirachta indica showed more inhibition zone against Vibrio cholerae and Bacillus subtilis, while E. coli and
S. typhi were less susceptible to neem extract, what is corroborated by our results.

This study was a first attempt which was carried out in parallel to the work of Sagoua (2009) on neem oil antifungal effect where they reported the effectiveness of the dose of $100 \mu \mathrm{L}$ on fungal strains of Colletotrichum musae on banana skin. Therefore, we tested the effect of NO incorporation directly into the nutrient medium.

Then, neem oil (NO) has been incorporated directly into the TSAN medium. The incorporation of $1 \%$ NO in TSAN medium reduced the growth of E. coli $\mathrm{K} 12$ by $19.6 \%$, but the growth decrease of $S$. enterica subsp. enteritidis (12.4\%) was not significantly different from the control (Figure 2).

Incorporating $\mathrm{NO}$ into the culture medium on the growth of bacteria is a common practice usually done for studying antimicrobial properties of plant extracts and synthetic compounds (Pu et al., 2010; Pai et al., 2004; Alzoreky and Nakahara, 2003; Pintore et al., 2002; Prudent et al., 1995). Our results however, are contradictory to those obtained by Sairam et al. (2000) who demonstrated that the incorporation of NO at $15 \mathrm{mg} \mathrm{mL}^{-1}$ in the nutrient broth did not inhibit the growth of E. coli, and that concentrations of 8 and $10 \mathrm{mg} \mathrm{mL}^{-1}$ (minimum inhibitory concentration or MIC) respectively inhibited two other species of Salmonella such as S. typhi and S. dysenteroides. According to Mamman et al. (2013), neem aqueous extracts, at a MIC of $43.75 \mathrm{mg} \mathrm{mL}^{-1}$ was found to inhibit the growth of Escherichia coli in nutrient broth and Salmonella spp. by $175 \mathrm{mg} \mathrm{mL}^{-1}$. Several studies reported that oil from the leaves, seeds and bark of the neem tree possesses a wide spectrum of antibacterial activity against Gram-negative and Gram-positive microorganisms (Raut et al., 2014). These authors have shown that Gram-negative bacteria, such as E. coli and Salmonella, were less sensitive to NO than Gram-positive bacteria, such as Bacillus subtilis. Our distinct method of incorporation of $\mathrm{NO}$ and the different culture medium used could explain these differences.

The rate of reduction of the number of colony forming units (CFU) obtained (19.2\% and $12.4 \%$ for E. coli $\mathrm{K} 12$ and $S$. enterica subsp. enteritidis, respectively) was found lower (by 50 to $90 \%$ ) in our study compared with other ones (Fabry et al., 1998). This is probably due to the incorpora-

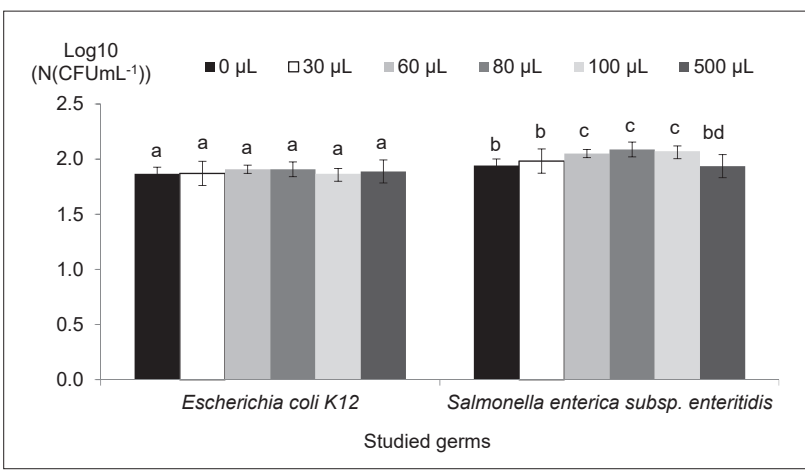

FIGURE 1. Effect of neem seed oil volatile compounds on the in vitro growth of Escherichia coli K12 and Salmonella enterica subsp. enteritidis. Data are means and error bars are LSD $(n=9)$. Mean values with different letters have significant difference $(P<0.05) .0,30,60,80,100$ and $500 \mu \mathrm{L}$ are neem seed oil doses deposed on a microscope strip fixed to the bottom of the Petri dish cover for testing as volatile; $\mathrm{N}$ : Bacterial charge (in E. coli and S. enterica) expressed in $\log 10$ CFU mL-1.

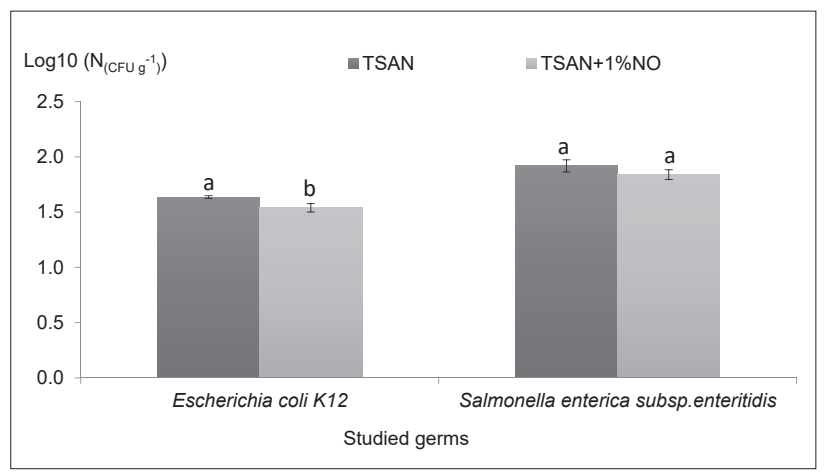

FIGURE 2. Effect of neem seed oil incorporation in the culture medium on the in vitro growth of Escherichia coli K12 and Salmonella enterica subsp. enteritidis. Data are means and error bars are LSD $(n=9)$. Mean values with different letters have significant difference $(P<0.05)$. TSAN: Control samples of culture medium without neem seed oil incorporation; TSAN $+1 \%$ NO: Samples of culture medium (TSAN) containing $1 \%(\mathrm{v} / \mathrm{v})$ neem seed oil; $\mathrm{N}$ : Bacterial charge expressed in Log10 CFU g-1. 

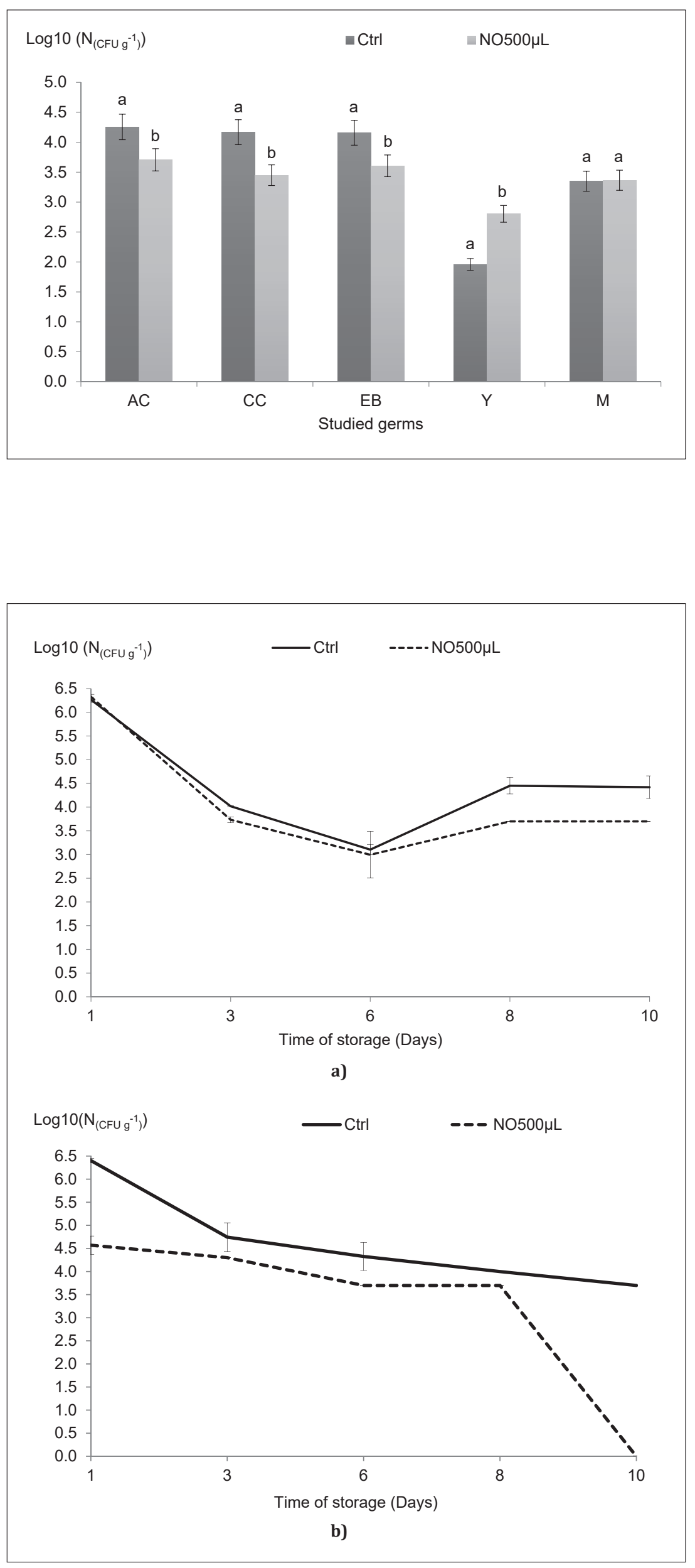

FigURE 3. Effect of neem seed oil volatile compounds on fresh-cut mango global microbiological quality. $\mathrm{N}$ : Bacterial charge expressed in Log10 CFU g- ${ }^{-1}$. Data are means and error bars are LSD $(n=3)$. Mean values with different letters have significant difference $(P<0.05)$. Ctrl: Control samples; N0500 $\mu \mathrm{L}$ : Samples treated with $500 \mu \mathrm{L}$ neem seed oil volatile. C: Aerobic count; CC: Coliforms count; EB: Enterobacteria; Y: Yeast; M: Mold.

FIGURE 4. Effect of neem seed oil volatile compounds on the in vivo growth of a) Escherichia coli K12, or b) Salmonella enterica subsp. enteritidis in fresh-cut mango. Data are means and error bars are LSD $(n=3)$. Ctrl: Control samples; N0500 $\mu \mathrm{L}$ : Samples treated with $500 \mu \mathrm{L}$ neem seed oil volatiles; $\mathrm{N}$ : Bacterial charge expressed in Log10 CFU g-1. Error bars are missing where $\mathrm{LSD}=0$. 


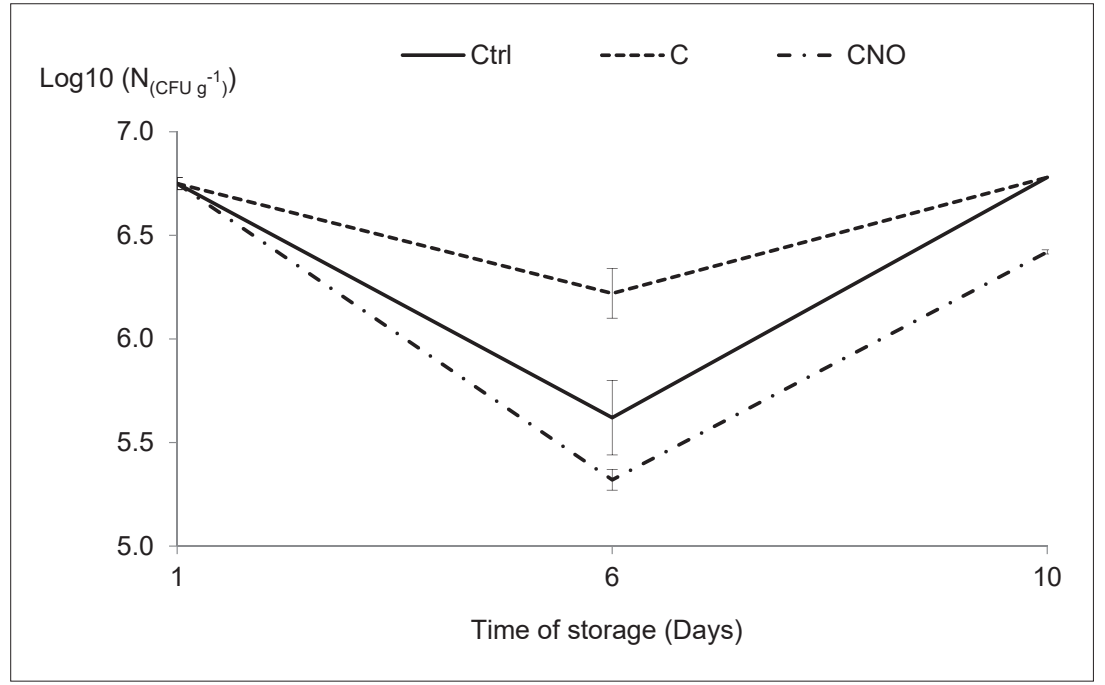

FIGURE 5. Effect of the incorporation of neem seed oil in the coating on the in vivo growth of Escherichia coli K12 during 10 days of storage at $4{ }^{\circ} \mathrm{C}$. Data are means and error bars are LSD $(n=9)$. Ctrl: Control samples; C: Samples treated with coating only; CNO: Samples treated with coating containing $1 \%(\mathrm{v} / \mathrm{v})$ neem seed oil; $\mathrm{N}$ : Bacterial charge expressed in CFU g-1. Error bars are missing where $\mathrm{LSD}=0$. tion in the growing medium of neem extracts from leaves at MIC and minimum bactericidal concentration (MBC) (Burt, 2004). The MIC is cited by many researchers as a measure of the antibacterial performance of essential oils (Burt, 2004), but its definition differs among the publications, what prevents clear comparison between studies. Technically speaking, the use of various growing media and broths to test bacteria should also be considered for comparing experimental results. Some of the cited studies show shortcomings in the reporting of inhibition, inactivation or reduction of bacterial and mold growth; similarly in the methods used for demonstrating the antibacterial activity of the compounds and extracts of neem seeds (Burt, 2004).

No standardized test has been developed for evaluating the antibacterial activity of potential preservatives against food-related microorganisms, although the need for such a test has been indicated (Davidson and Parish, 1989). With the evolution of molecular tools for characterizing natural compounds and industrial practices in food preservation, it is expected to find appropriate combinations between neem (Azadirachta indica A. Juss) and mango (Mangifera indica L.).

\section{Effect of neem oil volatile on the in vivo growth of pathogenic and spoilage flora in fresh-cut mango}

The study of neem seed oil (NO) volatile effects on the spoilage flora of fresh-cut mango offered the opportunity for a general evaluation of the antimicrobial effects of NO volatile compounds at the maximum dose of $500 \mu \mathrm{L}$. A significant reduction in the growth of the aerobic count, coliforms and enterobacteria was observed after 7 days of storage at $4{ }^{\circ} \mathrm{C}$. Such an effect of NO on the growth inhibition of coliforms such as E. coli has been previously demonstrated (Matthews et al., 2009; Mamman et al., 2013; Ravva and Korn, 2015). However, our NO extracts showed no effect on the growth in vivo of tested yeasts and molds. This is in contradiction with some studies (Sagoua, 2009; Mirza et al., 2000) carried out on some specific fungi such as Phytophthora infestans and Colletotrichum musae. Accordingly, it was necessary to study the effect of these volatile compounds on the in vivo growth of two pathogenic bacteria (Escherichia coli K12 and Salmonella enterica subsp. enteritidis), recognized as enteric pathogens for fresh-cut mango and their hazard for consumer health.

Neem oil (NO) volatile compounds affected the in vivo growth of two pathogenic bacteria: Escherichia coli K12 and Salmonella enterica subsp. enteritidis (Figures $4 \mathrm{a}$ and $4 \mathrm{~b}$, re- spectively). Regarding the growth of $E$. coli K12, $500 \mu \mathrm{L}$ NO volatiles reduced the microbial population at 8 and 10 days of storage (Figure 4a). For $S$. enterica subsp. enteritidis, a significant 4-log reduction of the growth was recorded after 10 days of storage (Figure $4 \mathrm{~b}$ ).

These results encouraged us to study the effect of incorporating neem oil $(1 \% \mathrm{v} / \mathrm{v})$ in a starch-based coating of Colocasia esculenta on the growth of the E. coli K12 only, since NO was non-effective on the growth of $S$. enterica subsp. enteritidis when incorporated in the growing medium. The growth of E. coli K12 decreased during the first 6 days and then increased (Figure 5) and this, whatever the storage conditions. Samples of coated mangoes (C) had the highest amount of $E$. coli $\mathrm{K} 12$, confirming that this coating was an additional source of nutrients for the bacteria. The incorporation of neem oil in the coating (CNO) reduced significantly the growth of E. coli after 6 and 10 days of storage, whereas the microorganisms in the control samples (Ctrl) and those coated (C) were uncountable after 10 days of storage. The application of $C$. esculenta starch based coating on fresh-cut mango was an original experiment performed in this work.

After the effectiveness of raw NO incorporation in Colocasia esculenta starch based coating on the pathogenic bacterial growth on fresh-cut mango, further investigation will be necessary to know the responsible active compound of neem seed oil that might be used on food. Some active compounds of NO were identified: nim-76, nimbidin, nimbolide, mahmoodin, margolone, margolonone, isomargolonone, 9-octadecanoic acid, hexadecanoic acid, tetrahydrofuran-3,4-diethyl ester, gedunin... as having antibacterial properties (Sunday and Joy, 2009; Pu et al., 2010; Biswas et al., 2002; Sairam et al., 2000). They would be subject to specific studies on the fresh-cut mango and its pathogenic flora to improve the microbiological safety of the food product.

\section{Conclusion}

This is the first study reporting the use of neem oil (NO) from seeds as potential antimicrobial substance against pathogenic and spoilage bacteria in fresh-cut fruit. This study showed that the NO volatile compounds were more effective in vivo than in vitro on the reduction of the growth of both pathogens studied: Escherichia coli K12 and Salmonella enterica subsp. enteritidis. The incorporation of NO in the growing medium as in Colocasia esculenta starch for coating at a concentration of $1 \%(\mathrm{v} / \mathrm{v})$ was beneficial for reducing the 
growth of Escherichia coli K12, and had almost no effect on Salmonella enterica subsp. enteritidis.

These results offer the possibility to use neem seed oil as an antimicrobial agent for fresh-cut fruits to control microorganisms such as coliforms like E. coli, which is a good indicator of the hygienic status and a regulatory germ in freshcut products for some countries. Its use in food will require however, further studies to check the most effective dosage of NO and its related detoxification and deodorization.

\section{References}

Almas, K. (1999). The antimicrobial effects of extracts of Azadirachta indica (neem) and Salvadora persica (Arak) chewing sticks. Indian J. Dent. Res. 10(1), 23-26.

Alzoreky, N.S., and Nakahara, K. (2003). Antibacterial activity of extracts from some edible plants commonly consumed in Asia. Int. J. Food Microbiol. 80(3), 223-230. https://doi.org/10.1016/S01681605(02)00169-1.

Biswas, K., Chattopadhyay, R.K., Banerjee, U., and Bandyopadhyay, U. (2002). Biological activities and medicinal properties of neem (Azadirachta indica). Cur. Sci. 82, 1336-1345.

Burt, S. (2004). Essential oils: their antibacterial properties and potential applications in food - a review. Int. J. Food Microbiol. 94(3), 223-253. https://doi.org/10.1016/j.ijfoodmicro.2004.03.022.

Das, N.G., Nath, D.R., Baruah, I., Talukdar, P.K., and Das, S.C. (1999). Field evaluation of herbal mosquito repellents. J. Commun. Dis. 31(4), 241-245.

Davidson, P.M., and Parish, M.E. (1989). Methods for testing the efficacy of food antimicrobials. Food Technol. 43, 148-155.

Fabry, W., Okemo, P., and Ansorg, R. (1998). Antibacterial activity of East African medicinal plants. J. Ethnopharmacol. 60, 79-84. https:// doi.org/10.1016/S0378-8741(97)00128-1.

Fabry, W., Okemo, P., and Ansorg, R. (1996). Fungistatic and fungicidal activity of east African medicinal plants. Mycoses 39(1-2), 67-70. https://doi.org/10.1111/j.1439-0507.1996.tb00087.x.

Mamman, P.H., Mshelia, W.P., Susbatrus, S.C., and Sambo, K.W. (2013). Antibacterial effects of crude extract of Azadirachta indica against Escherichia coli, Salmonella spp. and Staphylococcus aureus. Int. J. Medicine and Medical Sci. 5(1), 14-18.

Matthews, R.L., Templeton, M.R., Tripathi, S.K., and Bhattarai, K. (2009). Desinfection of waterborne coliform bacteria by neem oil. Envir. Eng. Sci. 26(9), 1435-1441. https://doi.org/10.1089/ ees.2009.0058.

Mirza, J.I., Hameed, S., Ahmad, I., Ayub, N., and Strang, R.H.C. (2000). In vitro antifungal activity of neem products against Phytophthora infantans. Pakistan J. Biol. Sci. 3(5), 824-828. https://doi. org/10.3923/pjbs.2000.824.828.

Pai, M.R., Acharya, L.D., and Udupa, N. (2004). Evaluation of antiplaque activity of Azadirachta indica leaf extract gel - a 6-week clinical study. J. Ethnopharmacol. 90(1), 99-103. https://doi. org/10.1016/j.jep.2003.09.035.

Pérez, E., Gibert, O., Rolland-Sabaté, A., Jimenez, Y., Sánchez, T., Girald, A., Pontoire, B., Guilois, S., Lahon, M.C., Reynes, M., and Dufour, D. (2011). Physicochemical, functional and macromolecular properties of waxy yam starches discovered from seven genotypes of 'Mapuey' (Dioscorea trifida) traditionally consumed in the Venezuelan Amazon. J. Agric. and Food Chem. 59, 263-273. https:// doi.org/10.1021/jf100418r.

Pintore, G., Usai, M., Bradesi, P., Juliano, C., Boatto, G., Tomi, F., Chessa, M., Cerri, R., and Casanova, J. (2002). Chemical composition and antimicrobial activity of Rosmarinus officinalis L. oils from Sardinia and Corsica. Flavour and Fragrance J. 17, 15-19. https://doi. org/10.1002/ffj.1022.

Prudent, D., Perineau, F., Bessiere, J.M., Michel, G.M., and Baccou, J.C. (1995). Analysis of the essential oil of wild oregano from Martinique (Coleus aromaticus Benth.) - evaluation of its bacteriostatic and fungistatic properties. J. Essential Oil Res. 7, 165-173. https://doi. org/10.1080/10412905.1995.9698492.

Pu, Z., Zhang, Y., Yin, Z., Xu, J., Jia, R., Lu, Y., and Yang, F. (2010). Antibacterial activity of 9-octadecanoic acid-hexadecanoic acid-tetrahydrofuran-3, 4-diyl ester from neem oil. Agric. Sci. in China 9(8), 1236-1240. https://doi.org/10.1016/S1671-2927(09)60212-1.

Raut, R.R., Sawant, A.R., and Jamge, B.B. (2014). Antimicrobial activity of Azadirachta indica (Neem) against pathogenic microorganisms. J. Acad. and Indust. Res. (JAIR) 3(7), 327-329.

Ravva, S.V., and Korn, A. (2015). Effect of neem (Azadirachta indica) on the survival of Escherichia coli 0157:H7 in dairy manure. Int. J. Envir. Res. and Public Health 12, 7794-7803. https://doi. org/10.3390/ijerph120707794.

Sagoua, W. (2009). Etude synergique du couplage du Système Lactoperoxydase avec d'autres molécules naturelles actives ayant des propriétés antifongiques pour l'amélioration de la conservation en frais des bananes. Thèse, Université d'Avignon et des Pays de Vaucluse, Avignon, France, 151 pp.

Sairam, M., Ilavazhagan, G., Sharma, S.K., Dhanraj, S.A., Suresh, B., Parida, M.M., Jana, A.M., Devendra, K., and Selvamurthy, W. (2000). Anti-microbial activity of a new vaginal contraceptive NIM-76 from neem oil (Azadirachta indica). J. Ethnopharmacol. 71, 377-382. https://doi.org/10.1016/S0378-8741(99)00211-1.

Sandhya (2010). Modified atmosphere packaging of fresh produce: Current status and future needs. LWT - Food Science and Technol. 43, 381-392. https://doi.org/10.1016/j.lwt.2009.05.018.

Strawn, L.K., and Danyluk, M.D. (2010). Fate of Escherichia coli 0157:H7 and Salmonella spp. on fresh and frozen cut mangoes and papayas. Int. J. Food Microbiol. 138, 78-84. https://doi. org/10.1016/j.ijfoodmicro.2009.12.002

Sunday, E.A., and Joy, C.A. (2009). Azadirachta indica (neem): a plant of multiple biological and pharmacological activities. Phytochem. Rev. 8, 601-620. https://doi.org/10.1007/s11101-009-9144-6.

Tapia, M.S., Pérez, E., Rodríguez, P., Guzmán, R., Ducamp-Collin, M.N., Tran, T., and Rolland-Sabaté, A. (2011). Evaluation of some properties of starch and starch edible films from sub-utilized roots and tubers from the Venezuelan Amazons. Original Article of BIOFOAMS Conference, 6 pp.

Uwimbabazi, F., Uwimana, J., and Rutanga, J.P. (2015). Assessment of antibacterial activity of Neem plant (Azadirachta indica) on Staphylococcus aureus and Escherichia coli. J. Med. Plants Studies 3(4), 85-91.

Vanka, A., Tandon, S., Rao, S.R., Udupa, N., and Ramkumar, P. (2001). The effect of indigenous neem (Azadirachta indica) [correction of Adirachta indica] mouth wash on Streptococcus mutans and lactobacilli growth. Indian J. Dent. Res. 12(3), 133-144.

World Health Organization (WHO) (2002). Food safety and foodborne illness (Geneva: World Health Organization). Fact sheet 237, revised January 2002

Received: Nov. 9, 2016

Accepted: Jan. 13, 2017 